\section{Immune response of blue mussels (Mytilus edulis) in spawning period following exposure to metals}

\author{
M. Fraser ${ }^{1,2}$ P. Rault, ${ }^{3}$ M. Fortier, ${ }^{1}$ \\ P. Brousseau, ${ }^{1}$ M. Fournier, ${ }^{1}$ C. Surette ${ }^{4}$ C. \\ Vaillancourt ${ }^{1,2}$
}

'INRS - Institut Armand-Frappier, Laval, QC, Canada; 'BioMed Research Centre, Université du Québec, Laval, QC, Canada; IInstitut Universitaire Européen de la Mer, Université de Bretagne Occidentale, Plouzané, France; ${ }^{4}$ Université de Moncton, Département de chimie et de biochimie, Moncton, NB, Canada

\section{Introduction}

Mytilus edulis are sensitive to environmental contamination like metals, such as silver (Ag), lead $(\mathrm{Pb})$, cadmium $(\mathrm{Cd})$ and mercury $(\mathrm{Hg})$, which are bioavailable for this species. ${ }^{1-3}$ It is well documented that these metals can disrupt the immune responses in bivalves. ${ }^{4-6}$ During spawning, important physiological systems are involved, such as serotonin and dopamine, ${ }^{7-11}$ which in turn could modulate the immune system. ${ }^{12,13}$ Indeed, bivalves reduce their metabolic activity after spawning which is reflected by a decrease of the phagocytosis activity. ${ }^{14-18}$ It is expected that during the period of reduced immune activity (i.e., after spawning) mussels are more vulnerable to contaminations and diseases. ${ }^{14-16,18,19}$ The aim of this pilot study was to determine if spawning modulates immune responses of Mytilus edulis exposed to metals $(\mathrm{Ag}, \mathrm{Cd}, \mathrm{Hg}$ and $\mathrm{Pb})$.

\section{Materials and Methods}

\section{Mussels}

Mytilus edulis were collected from the Baie de Plaisance located in the Îles de la Madeleine region (QC, Canada) $\left(47^{\circ} 29^{\prime} \mathrm{N}, 61^{\circ} 87^{\prime} \mathrm{W}\right)$, an area clear from industrial and urban activities. Upon arrival at the laboratory, the mussels were transferred and maintained in tank filled with artificial seawater $\left(15^{\circ} \mathrm{C}\right.$, salinity $31-1$ psu) and fed twice a week with a concentrate of phytoplankton (Phytoplex , Reef solution, Laval, QC, Canada). Mussels were sacrificed one week before (W-1) spawning, during (W0) spawning, two and three weeks after spawning period (W2 and W3 respectively). The spawning period was determined by the release of gametes in the water. Hemolymph was collected from the posterior adductor muscle of each mussel using a $3 \mathrm{~mL}$ syringe and immediately used for analysis.

\section{Metal exposure}

Mussel hemocytes were exposed in vitro to increasing metal concentrations ( $\mathrm{n}=3$ by metal): one metal at a time during 21 hours $\left(\mathrm{Ag}, \mathrm{Cd}, \mathrm{Hg}\right.$ and $\mathrm{Pb} ; 10^{-9}$ to $\left.10^{-3} \mathrm{M}\right)$. Metals used are reagent grade: cadmium chloride $\left(\mathrm{CdCl}_{2}\right)$, lead chloride $\left(\mathrm{PbCl}_{2}\right)$, mercuric chloride $\left(\mathrm{HgCl}_{2}\right)$ and silver nitrate $\left(\mathrm{AgNO}_{3}\right)$ (SigmaAldrich, ON, Canada).

\section{Cell viability}

The viability of hemocytes was evaluated by flow cytometry using the Guava PCA flow cytometer (Guava Technologies, CA, US) and the Viacount kit (Guava Technologies) according to the supplier's instructions. Briefly, an aliquot of hemolymph was mixed with Viacount and 1000 events were recorded.

\section{Phagocytosis of hemocytes}

Phagocytosis was assessed by flow cytometry according to Brousseau et al. ${ }^{20}$ Briefly, hemocytes were incubated with latex fluorescent beads (Yellow-green Fluoresbrite, Polysciences $\left.{ }^{\circledR}\right)$. The number of engulfed beads in each hemocyte was determined using a FACSCalibur (Becton-Dickinson, CA, USA) flow cytometer. Fluorescence emission was read in FL1 $(\lambda=530 \mathrm{~nm})$, with at least 10000 events in the region of interest were recorded. Results were analyzed with the Cell Quest Pro software (Becton-Dickinson, CA, USA) to determine the percentage of hemocytes that engulfed one bead and more (phagocytic activity) or three beads and more (phagocytic efficiency).

\section{Statistical analysis}

Data are presented as mean standard error of the mean (SEM). The results were tested for normality by the Kolmogorov-Smirnov test. Variance homogeneity was verified by Levene's test. Significant differences were determined using ANOVA or Kruskal-Wallis. SPSS 20.0 was used for all statistical analyses (IBM Corp., 2011, IL, USA). Half maximal inhibitory concentrations $\left(\mathrm{IC}_{50}\right)$ were determined with GraphPad Prism 5.0a (GraphPad Software Inc., 2007, CA, USA).

\section{Results and Discussion}

Phagocytic capacity and efficiency of hemocytes from Mytilus edulis during spawning period are $60 \%$ lower than those from mussels after the spawning period (Figure 1). This observation is consistent with previous studies. ${ }^{14,18,19}$ Li et al. suggest a trade-off of the energy to the spawning process to explain the effects observed since glycogen and protein levels in the mantle of Pacific oysters also
Correspondence: Michel Fournier and Cathy Vaillancourt, INRS - Institut Armand-Frappier, Université du Québec, Laval, QC, Canada. E-mail: cathy.vaillancourt@iaf.inrs.ca; michel.fournier@iaf.inrs.ca

Key words: mussel hemocytes, phagocytosis, cadmium, lead, mercury, silver.

Conference presentation: ECOBIM meeting, 2014 May, Brest, France.

Contributions: $\mathrm{MF}$ and $\mathrm{CV}$ contributed equally.

This work is licensed under a Creative Commons Attribution NonCommercial 3.0 License (CC BYNC 3.0).

(C) Copyright M. Fraser et al., 2014

Licensee PAGEPress, Italy

Journal of Xenobiotics 2014; 4:4895

doi:10.4081/xeno.2014.4895

decreased during this period. ${ }^{14}$ As suggested by Cartier et al., it is possible that the increased level of sex steroid hormones during spawning period plays a suppressive role on the immune system. ${ }^{19,21,22}$ This possibility was verified in the common carp, where $17 \beta$-estradiol, progesterone and 11-ketotestosterone were shown to inhibit phagocytosis..$^{20}$ More studies should be done to explain how the immune system of Mytilus edulis could be affected by spawning. Since sex can also influence the immune and endocrine systems of bivalves, ${ }^{23,24}$ it should be included in such studies.

Fourteen days after spawning, phagocytic capacity and efficiency of hemocytes return to the baseline levels founds before spawning period (Figure 1). In the pacific oysters, a

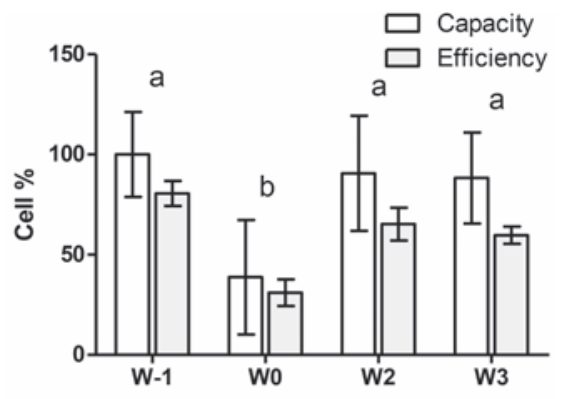

Figure 1. Phagocytic capacity and efficiency of hemocytes from Mytilus edulis according to spawning period. Mussels were sacrificed one week before (W-1) spawning, during (W0) spawning, two and three weeks after spawning period (W2 and $\mathrm{W} 3$, respectively).Different letters indicate, for capacity and efficiency, a significant difference (ANOVA, $\mathrm{P}<\mathbf{0 . 0 0 0 1}$ ). 
A

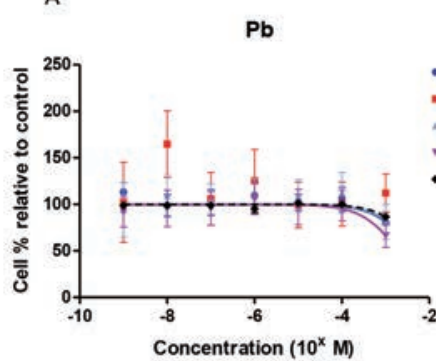

C

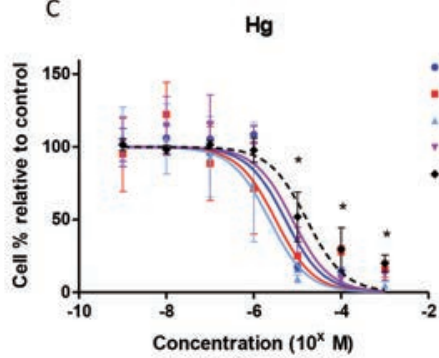

B
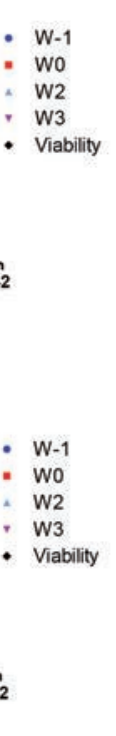

Cd
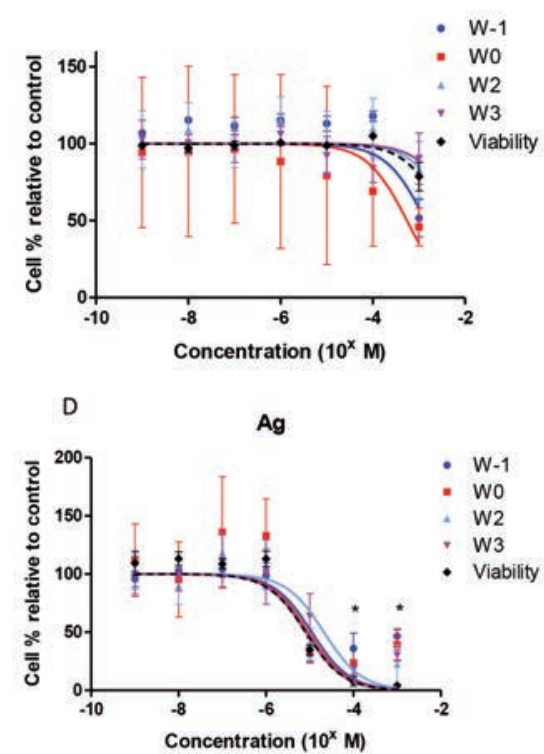

Figure 2. Phagocytic capacity and viability of hemocytes exposed to metals [A: lead (Pb), B: cadmium (Cd), C: mercury ( $\mathrm{Hg}$ ) and $\mathrm{D}$ : silver $(\mathrm{Ag})]$ from Mytilus edulis in or out spawning period. Mussels were sacrificed one week before (W-1) spawning, during (W0) spawning, two and three weeks after spawning period (W2 and W3, respectively). Controls were not exposed to metals. To compare difference between concentrations: *ANOVA/Kruskal-Wallis $\mathbf{P}<0.05$.

recovery is observed 8 days after the possible that some mussels sacrificed were

Table 1. Inhibitory concentrations (IC50) of phagocytic capacity of hemocytes exposed to metals in or out spawning period (expressed in $\left.10^{\wedge} \mathrm{x} M\right)$.

\begin{tabular}{lcccc} 
& $\mathrm{Pb}$ & $\mathrm{Cd}$ & $\mathrm{Hg}$ & $\mathrm{Ag}$ \\
W-1 & $>-3$ & $>-3$ & $-5 . \pm 0.2$ & $-5.1 \pm 0.2$ \\
W0 & $>-3$ & $-3 . \pm 0.7$ & $-5.5 \pm 0.3$ & $-5.0 \pm 0.5$ \\
\hline W2 & $>-3$ & $>-3$ & $-5.6 \pm 0.1$ & $-5.0 \pm 0.2$ \\
W3 & $>-3$ & $>-3$ & $-5.1 \pm 0.2$ & $-4.7 \pm 0.3$ \\
\hline Viability & $>-3$ & $>-3$ & $-4.8 \pm 0.2$ & $-5.1 \pm 0.1$ \\
\hline
\end{tabular}

$\mathrm{Pb}$, lead; Cd, cadmium; Hg, mercury; Ag, silver. W-1, one week before spawning; W0, during spawning; W2, two weeks after spawning; W3, three weeks after spawning.

spawning. ${ }^{14}$ Future experiment should include more time points to better understand the recovery of immune system of Mytilus edulis after spawning.

A significant decrease in hemocytes viability exposed to $\mathrm{Ag}$ and $\mathrm{Hg}$ at $10^{-5} \mathrm{M}$ was observed independently of the spawning period (Figure $2 \mathrm{C}$ and $\mathrm{D})$. A decreased in phagocytic capacity was associated.

Spawning did not affect phagocytic capacity following an exposure to $\mathrm{Ag}, \mathrm{Hg}$ and $\mathrm{Pb}$ (Figure 2 A, C, D and Table 1). However, spawning decreased the phagocytic capacity of mussel hemocytes exposed to $\mathrm{Cd}$ (Figure 2B and Table 1). Thus, mussels in spawning period exposed to $\mathrm{Cd}$ could be more vulnerable to diseases than those not exposed to $\mathrm{Cd}$, this remains to be examined further. ${ }^{14-16,18,19}$

Since spawning period was determined by the observation of gametes in the water, it is still not in spawning process. Future experiments should include histological analysis of the gonads in order to determine the gametogenesis stage and the sex of each mussel. Nevertheless, this preliminary pilot study demonstrates the importance of considering the stage of reproduction of Mytilus edulis in studies of the immune system.

\section{References}

1. Fraser M, Surette C, Vaillancourt C. Spatial and temporal distribution of heavy metal concentrations in mussels (Mytilus edulis) from the Baie des Chaleurs, New Brunswick, Canada. Marine Pollut Bull 2011;62:1345-51.

2. Phillips DJH. The common mussel Mytilus edulis as an Indicator of pollution by zinc, cadmium, lead and copper. I. Effects of environmental variables on uptake of metals. Mar Biol 1976;38:59-69.

3. Phillips DJH. The common mussel Mytilus edulis as an indicator of pollution by zinc, cadmium, lead and copper. II. Relationship of metals in the mussel to those discharged by industry. Mar Biol 1976;38:71-80.

4. Gagnaire B, Thomas-Guyon H, Renault T. In vitro effects of cadmium and mercury on Pacific oyster, Crassostrea gigas (Thunberg), haemocytes. Fish Shellfish Immunol 2004;16:501-12.

5. Rault P, Fortier M, Pédelucq J, Lacaze E, Brousseau P, Auffret $M$, et al. Immunotoxicity of heavy metals (silver, cadmium, mercury and lead) on marine bivalve Mytilus edulis: in vitro exposure of hemocytes. J Xenobiotics 2013;3(s1):e8.

6. Bruneau A, Fortier M, Gagne F, Gagnon C, Turcotte P, Tayabali A, et al. In vitro immunotoxicology of quantum dots and comparison with dissolved cadmium and tellurium. Environ Toxicol 2013 [In press].

7. Morse DE, Duncan H, Hooker N, Morse A. Hydrogen peroxide induces spawning in mollusks, with activation of prostaglandin endoperoxide synthetase. Science 1977; 196:298-300.

8. Gagne F, Fournier M, Blaise C. Serotonergic effects of municipal effluents: Induced spawning activity in freshwater mussels. Fresenius Environ Bull 2004;13:1099-103.

9. Matsutani T, Nomura T. In vitro effects of serotonin and prostaglandins on release of eggs from the ovary of the scallop, Patinopecten yessoensis. General Comparat Endocrinol 1987;67:111-8.

10. Martínez G, Mettifogo L, Lenoir R, Olivares A. Prostaglandins and reproduction of the scallop Argopecten purpuratus: II. Relationship with gamete release. J Exp Zool 2000;287:86-91.

11. Fong PP, Noordhuis R, Ram JL. Dopamine reduces intensity of serotonin-induced spawning in the zebra mussel Dreissenapolymorpha (pallas). J Exp Zool 1993;266: 79-83.

12. Li J-T, Lee P-P, Chen O-C, Cheng W, Kuo CM. Dopamine depresses the immune ability and increases susceptibility to Lactococcus garvieae in the freshwater giant prawn, Macrobrachium rosenbergii. Fish Shellfish Immunol 2005;19:269-80.

13. Cheng W, Chieu H-T, Tsai C-H, Chen J-C. Effects of dopamine on the immunity of white shrimp Litopenaeus vannamei. Fish Shellfish Immunol2005;19:375-85.

14. Li Y, Qin JG, Li X, Benkendorff K. Assessment of metabolic and immune changes in postspawning Pacific oyster Crassostrea gigas: identification of a criti- 
cal period of vulnerability after spawning. Aquacult Res 2010;41:e155-e65.

15. Li Y, Qin JG, Abbott CA, Li X, Benkendorff K. Synergistic impacts of heat shock and spawning on the physiology and immune health of Crassostrea gigas: an explanation for summer mortality in Pacific oysters. Am J Physiol Regul Integr Comparat Physiol 2007;293:R2353-R62.

16. Li Y, Qin JG, Li X, Benkendorff K. Spawning-dependent stress responses in pacific oysters Crassostrea gigas: a simulated bacterial challenge in oysters. Aquaculture 2009;293:164-71.

17. Rasmussen LPD, Hage E, Karlog 0. An electron microscope study of the circulating leucocytes of the marine mussel, Mytilus edulis. J Invertebrate Pathol 1985;45:158-67.

18. Fraser M, Rault P, Roumier P-H, Fortier M,
André C, Brousseau P, et al. Decrease in phagocytosis capacity of hemocyte during spawning in Mytilus edulis: a pilot study. J Xenobiotics 2013;3(s1):e12.

19. Cartier S, Pellerin J, Fournier M, Tamigneaux E, Girault L, Lemaire N. Use of an index based on the blue mussel (Mytilus edulis and Mytilus trossulus) digestive gland weight to assess the nutritional quality of mussel farm sites. Aquaculture 2004;241:633-54.

20. Brousseau P, Payette Y, Tryphonas H, Blakley B, Boernaus H, Flipo D, et al. Manual of immunological methods. Boca Raton, FL: CRS Press; 1999.

21. Reis-Henriques MA, Le Guellec D, RemyMartin JP, Adessi GL. Studies of endogenous steroids from the marine mollusc Mytilus edulis L. By gas chromatography and mass spectrometry. Comparat
Biochem Physiol Part B Comparat Biochem 1990;95:303-9.

22. Watanuki H, Yamaguchi T, Sakai M. Suppression in function of phagocytic cells in common carp Cyprinus carpio L. injected with estradiol, progesterone or 11ketotestosterone. Comp Biochem Physiol C Toxicol Pharmacol 2002;132:407-13.

23. Cubero-Leon E, Ciocan CM, Hill EM, Osada M, Kishida M, Itoh N, et al. Estrogens disrupt serotonin receptor and cyclooxygenase mRNA expression in the gonads of mussels (Mytilus edulis). Aquatic Toxicol 2010;98:178-87.

24. Dang C, Tan T, Moffit D, Deboutteville JD, Barnes AC. Gender differences in hemocyte immune parameters of bivalves: the Sydney rock oyster Saccostrea glomerata and the pearl oyster Pinctada fucata. Fish Shellfish Immunol 2012;33:138-42. 